\title{
REFERENCES
}

Bellows, J. G. (1936). Arch. Ophthal., N.Y., 16, 60.

Bellows, J. G. (1944). Cataract and Anomalies of the Lens. London: H. Kimpton.

Friedenwald, J. S., Buschke, W. \& Michel, H. O. (1943). Arch. Ophthal., N.Y., 29, 535.

Johnson, S. W. (1936). Biochem. J. 30, 1430.

Mann, I. \& Pullinger, B. D. (1942). Proc. Roy. Soc. Med. 35, 229.
Müller, H. K. (1933). Nature, Lond., 132, 280.

Philpot, F. J. \& Pirie, A. (1943). Biochem. J. 37, 250.

Pullinger, B. D. \& Mann, I. (1943). J. Path. Bact. 55, 151.

Ralli, F. P. \& Sherry, S. (1941). Medicine, Baltimore, 20, 251.

Sullmann, H. \& Schmidt, A. E. (1942). Ophthalmologica, 103, 150.

Wolbach, S. B. (1933). Amer. J. Path. 9, Suppl., 689.

\section{The Manometric Determination of Formic Acid}

\author{
By N. W. PIRIE, Rothamsted Experimental Station, Harpenden, Herts
}

(Received 13 October 1945)

In spite of much effort there is no wholly satisfactory method for the estimation of small amounts of formic acid. Most of the methods that have been published depend on the fact that this acid is a volatile reducing agent, but its volatility is rather low and the specific estimation of a reducing agent in biological material is notoriously difficult. Two methods that do not depend on these properties have been described. One involves the liberation of carbon monoxide on treatment with strong sulphuric acid; it has been much used for the recognition of formic acid, but it has not been adapted for convenient analytical use. The other involves the reduction to formaldehyde by magnesium (Fenton \& Sisson, 1908; Droller, 1932) and the colorimetric estimation of the formaldehyde. This method appears in several text-books (e.g. Snell \& Snell, 1937), but in my hands it has proved unsatisfactory and Pickett, Ley \& Zygmuntowicz (1944) have likewise been unsuccessful with it.

Mixtures of volatile acids have been analyzed by collecting and titrating separately several fractions of distillate. The rates of distillation of the individual acids are known so that, by solving a series of simultaneous equations, the composition of mixtures of three or four acids can be ascertained (Hillig \& Knudsen, 1942; McClendon, 1944; McNair, 1933). Formic acid distils more slowly than other unsubstituted fatty acids, but it is not clearly differentiated from some of the substituted acids. Distillation has, therefore, generally been used simply as a means of preliminary separation from other components of the mixture. The same result has also been achieved by extracting the formic acid from aqueous solution with an immiscible solvent. This procedure is especially suitable when the effects of acid distillation must be avoided as, for example, when the course of an acid hydrolysis is being followed (Miles \& Pirie, 1939) or when free formic acid is being estimated in the presence of components that would give rise to formic acid during acid distillation (Claren, 1942). The method is, however, inconvenient, for no solvent is known with a very favourable partition coefficient and with most solvents the extraction becomes less efficient as it becomes more complete.

Mercuric salts are relatively specific oxidizing agents and they have been most commonly used in the final stage of the estimation, but a wide range of other agents has also been proposed. Among these permanganate (Klein, 1887), bromine (Joseph, 1910) and chromic acid (Tsiropinas, 1917) may be mentioned. These agents have been used in work more recent than that quoted and the reactions have been followed in a wide variety of ways, but all have been severely condemned as relatively unspecific. Stanier \& Massart (1935) claim a greater specificity for periodate and Pickett et al. (1944) find that ceric sulphate, under defined conditions in which the action is followed by estimation of the $\mathrm{CO}_{2}$ produced, has a specificity similar to that of mercuric salts. If small amounts of formic acid are being estimated, this ceric method would appear to be the most suitable of those already published.

The early literature on the use of mercuric salts for the oxidation was surveyed by Fincke (1913), and he defined the conditions necessary for quantitative oxidation and listed most of the substances that are liable to interfere with the reaction. Fincke weighed the mercurous chloride formed as a result of the action and this technique has been used by Auerbach \& Zeglin (1922) and others, although the physical properties of mercurous chloride make it difficult to manipulate small amounts quantitatively. It has 
also been determined by solution in an excess of iodine and back titration (Riesser, 1923; de Eds, 1924). A method depending on the titration of the hydrochloric acid that is produced during the oxidation was described by Fuchs (1929). Osburn, Wood \& Werkman (1933) improved the mercuric method greatly by estimating the $\mathrm{CO}_{2}$ formed from the formic acid, for by this means the interference by most other volatile reducing agents is circumvented. Technical improvements in the method were described by Weihe \& Jacobs (1936) and by Reid \& Weihe (1938), but the method was still suitable only for large (50-100 mg.) quantities of formic acid.

\section{METHOD}

The Markham (1942) distillation unit is very suitable for the preliminary separation of the formic acid; it was indeed for this separation that the unit was originally designed. In the method to be described there is no advantage in having a small volume of distillate; no use has therefore been made of the various agents, such as magnesium sulphate (Olmsted, Whitaker \& Duden, 1929), tetrachloroethylene (Claren, 1942), or benzene (Schicktanz, Steele \& Blaisdell, 1940), which accelerate the distillation of formic acid. Manometric determination of the $\mathrm{CO}_{2}$ is an obvious step in the adaptation of the mercuric method to the determination of small amounts of formic acid. The conditions necessary for complete oxidation by mercuric salts are now well known and, since they involve heating the mixture at $100^{\circ}$, a Van Slyke manometer with a detachable reaction vessel is used rather than a Warburg manometer.

A $1 \mathrm{ml}$., or at most $1.5 \mathrm{ml}$., sample containing $0 \cdot 1-1.0 \mathrm{mg}$. of formic acid and sufficient sulphuric acid to make it normal is pipetted into the Markham unit and steam distilled till $40 \mathrm{ml}$. of distillate have collected. The distillate is titrated with $0.02 \mathrm{~N}$ $\mathrm{NaOH}$, with methyl red as indicator, and when the end-point is reached a further $0.1 \mathrm{ml}$. is added; the slightly alkaline fluid is then boiled down to $3-4 \mathrm{ml}$. on a hot plate. It is quantitatively transferred to a $10 \mathrm{ml}$. test-tube having a B 14 interchangeable ground-glass joint, and evaporated in this to dryness in an oven at $100^{\circ}$. The indicator present shows whether a further drop of alkali is needed to keep the residue alkaline.

The oxidizing solution contains $8 \% \mathrm{HgCl}_{2}, 2 \%$ sodium acetate $\left(\mathrm{C}_{2} \mathrm{H}_{3} \mathrm{O}_{2} \mathrm{Na}+3 \mathrm{H}_{2} \mathrm{O}\right)$ and $2 \%$ acetic acid; $1 \mathrm{ml}$. of this is added to the dry residue in the test-tube. An ungreased ground stopper carrying a carefully greased stopcock is inserted and worked firmly home; a drop of water is used to seal the annulus and more is added should this evaporate during the heating. The tube is exhausted on a filter pump and kept on the pump for about a minute while being gently tapped; this removes all but a trace of the $\mathrm{CO}_{2}$ that will have been absorbed during the evaporation. With the tube evacuated, the stopcock is turned off and sealed with a drop of mercury. When the set of tubes has been prepared in this way it is half immersed in boiling water for $20 \mathrm{~min}$. There is some condensation in the cooler parts of the tube with consequent risk that some formic acid may escape oxidation, but the precipitate of calomel causes periodic bumping in the evacuated tube and so maintains complete mixing.

For the transfer and measurement of the $\mathrm{CO}_{2}$ the reagents of Van Slyke \& Folch (1940) are used and their technique is followed closely in so far as it is relevant to this determination. The mercury is emptied from the open part of the test-tubestopcock and it is replaced by 2 drops of $70 \%(\mathrm{v} / \mathrm{v})$ sulphuric acid; when this runs into the reaction mixture it assists in the transfer of the $\mathrm{CO}_{2} .2 \mathrm{ml}$. of $0.5 \mathrm{~N}-\mathrm{NaOH}$ is introduced into the chamber of the Van Slyke apparatus and its side tube is connected to the open part of the test-tube stopcock by a short piece of pressure tubing. Gaseous connexion is now made by opening the test-tube stopcock and then, after lowering the mercury and $0.5 \mathrm{~N}-\mathrm{NaOH}$ part of the way down the main chamber of the Van Slyke apparatus, opening the stopcock above the Van Slyke chamber. $\mathrm{CO}_{2}$ is transferred by lowering and raising the mercury reservoir five times and shaking the test-tube while the reservoir is being lowered. After the fifth lowering the tap at the top of the Van Slyke chamber is closed and the entrapped gas is expelled. A further five excursions of the reservoir with the taps open as before completes the transfer of the $\mathrm{CO}_{2}$.

The test-tube is now removed from the side arm of the Van Slyke apparatus which is sealed with mercury before proceeding to the de-aeration and liberation of the $\mathrm{CO}_{2}$ by addition of lactic acid in the manner described by Van Slyke \& Folch (1940). From the tables given in that paper $1 \mathrm{mg}$. of formic acid should give rise to $186 \mathrm{~mm}$. pressure of $\mathrm{CO}_{2}$ at $20^{\circ}$ and $2 \mathrm{ml}$. A long series of determinations carried out on known amounts of formic acid during the last 3 years has given results within $1 \mathrm{~mm}$. of the expected value. The uncertainty is therefore less than $1 \%$ with $1 \mathrm{mg}$. quantities of formic acid, but rises to 5 or $10 \%$ with $0.1 \mathrm{mg}$. quantities.

\section{Specificity and behaviour of formyl compounds}

In this method only substances that steam distil from acid solution and that do not evaporate again from alkaline solution are exposed to oxidation by mercuric chloride and they affect the estimation only if they are oxidized to $\mathrm{CO}_{2}$. The specificity of the action has been thoroughly investigated by the authors quoted already. It is known that volatile or slightly volatile acids such as benzoic, lactic, laevulinic or salicylic do not interfere; pyruvic acid 
reduces mercuric chloride but very little $\mathrm{CO}_{2}$ is formed in the action. In the work for which this method was required, phenol was a probable constituent of the fluids being analyzed. Neither pure phenol nor the dark-coloured products that arise when neutral phenol solutions are exposed to light and air give any detectable $\mathrm{CO}_{2}$ when tested in 5 mg. quantities. They do, however, precipitate with the mercury reagent and would interfere if the gravimetric method of estimation were used.

Formic acid not only occurs free in biological materials but $N$-formyl derivatives (Miles \& Pirie, 1939) and formyl esters (Gunde \& Hilditch, 1938) have been found. It is well known that many carbohydrates slowly yield formic acid when heated with acids and this process may complicate the issue when formic acid is being derived by the acid hydrolysis of an incompletely fractionated material. Agar breaks down exceptionally readily in this way and so do the soluble materials derived from it by procedures used in the preparation of biological media. The latter are common contaminants of fractions separated from agar-grown bacteria. In Table 1 the effect of different periods of hydrolysis on the apparent formyl content of agar and of the main antigen from Brucella abortus are compared. From this table it is clear that the conditions of hydrolysis that are needed to liberate $90 \%$ of the formic acid from the abortus antigen produce little formic acid from agar. The conditions are similar
Table 1. Influence of period for which hydrolysis is carried out on apparent formyl content of polysaccharides

\begin{tabular}{|c|c|c|c|c|}
\hline \multirow{2}{*}{$\begin{array}{c}\text { Time of } \\
\text { hydrolysis } \\
\text { at } 100^{\circ} \\
\text { with } \\
\mathrm{N}^{-} \mathrm{H}_{2} \mathrm{SO}_{4} \\
\text { (min.) }\end{array}$} & \multicolumn{4}{|c|}{$\begin{array}{c}\text { Yield of formic acid } \\
\text { (mg./100 mg. of material) }\end{array}$} \\
\hline & $\begin{array}{l}\text { Brucella } \\
\text { abortus } \\
\text { antigen }\end{array}$ & Agar & $\begin{array}{l}\text { Soluble } \\
\text { component } \\
\text { of agar }\end{array}$ & Starch \\
\hline 17 & $5 \cdot 1$ & - & $\overline{0}$ & - \\
\hline 30 & $5 \cdot 7$ & - & 0.47 & - \\
\hline 45 & $5 \cdot 7$ & 一 & 一 & - \\
\hline 60 & $5 \cdot 9$ & 0.97 & 0.84 & - \\
\hline 120 & $6 \cdot 2$ & - & $2 \cdot 5$ & - \\
\hline 240 & $6 \cdot 5$ & $5 \cdot 4$ & $5 \cdot 7$ & $0 \cdot 16$ \\
\hline
\end{tabular}

to those necessary with the closely related $B r$. melitensis antigen (Miles \& Pirie, 1939). Unless a formyl derivative should need much more vigorous hydrolysis than this there should be no difficulty in distinguishing between formic acid derived by hydrolysis and that derived by the more general destruction of a carbohydrate.

\section{SUMMARY}

1. A technique for the manometric estimation of the $\mathrm{CO}_{2}$ produced by the oxidation of formic acid by mercuric chloride is described. It is suitable for $1 \cdot 0-0 \cdot 1 \mathrm{mg}$. quantities.

2. The rates of formation of formic acid from agar and Brucella abortus antigen are compared.

\section{REFERENCES}

Auerbach, F. \& Zeglin, H. (1922). Z. phys. Chem. 103, 161.

Claren, O. B. (1942). Hoppe-Seyl. Z. 276, 97.

de Eds, F. (1924). J. Lab. clin. Med. 10, 59.

Droller, H. (1932). Hoppe-Seyl. Z. 211, 57.

Fenton, H. J. H. \& Sisson, H. A. (1908). Proc. Camb. Phil. Soc. 14, 385.

Fincke, H. (1913). Biochem. Z. 51, 253.

Fuchs, P. (1929). Z. anal. Chem. 78, 125.

Gunde, B. G. \& Hilditch, T. P. (1938). J. chem. Soc. p. 1980.

Hillig, F. \& Knudsen, L. F. (1942). J. Ass, off. agric. Chem. $25,176$.

Joseph, A. F. (1910). J. Soc. chem. Ind., Lond., 29, 1189.

Klein, J. (1887). Arch. Pharm., Berl., 225, 522.

Markham, R. (1942). Biochem. J. 36, 790.

McClendon, J. F. (1944). J. biol. Chem. 154, 357.

McNair, J. B. (1933). J. Amer. chem. Soc. 55, 1470.

Miles, A. A. \& Pirie, N. W. (1939). Biochem. J. 33, 1709.
Olmsted, W. H., Whitaker, W. M. \& Duden, C. W. (1929). J. biol. Chem. 85, 109.

Osburn, O. L., Wood, H. G. \& Werkman, C. H. (1933). Industr. Engng Chem. (Anal. ed.), 5, 247.

Pickett, M. J., Ley, H. L. \& Zygmuntowicz, N. S. (1944). J. biol. Chem. 156, 303.

Reid, J. D. \& Weihe, H. D. (1938). Industr. Engng Chem. (Anal. ed.), 10, 271.

Reisser, O. (1923). Biochem. Z. 142, 280.

Schicktanz, S. T., Steele, W. I. \& Blaisdell, A. C. (1940). Industr. Engng Chem. (Anal. ed.), 12, 320.

Snell, F. D. \& Snell, C. T. (1937). Colorimetric Methods of Analysis. New York: Van Nostrand.

Stanier, C. \& Massart, J. (1935). Chim. et Industr. 35, 1052.

Tsiropinas, F. (1917). Industr. Engng Chem. 8, 1110.

Van Slyke, D. D. \& Folch, J. (1940). J. biol. Chem. 136, 509.

Weihe, H. D. \& Jacobs, P. B. (1936). Industr. Engng Chem. (Anal. ed.), 8, 44. 